\title{
Adverse events of inactivated COVID-19 vaccine in HIV-infected adults
}

\author{
Songjie $\mathrm{Wu}^{1+}{ }^{1+}$, Yubin Zhang ${ }^{2 \dagger}$, Fangzhao Ming ${ }^{2 \dagger}$, Shi Zou ${ }^{3}$, Mengmeng $\mathrm{Wu}^{3}$, Wei Guo ${ }^{4,5}$, Weiming Tang ${ }^{6,7^{*}}$ and \\ Ke Liang ${ }^{1,3,8,9,10^{*} \text { (D) }}$
}

\begin{abstract}
This study aims to evaluate the safety of inactivated COVID-19 vaccine among adult people living with HIV (PLWH). In total, 259 PLWH who received at least one dose of inactivated COVID-19 vaccine were enrolled, and post-vaccination adverse events (AEs) were evaluated seven days following each vaccination dose. The overall AE frequency was $22.8 \%$ after dose one, which was higher than after dose two (10.2\%) $(P<0.001)$. No severe side event or vaccine safety concern was observed. Our finding was essential in reducing vaccine hesitancy among PLWH.
\end{abstract}

Keywords: People living with HIV(PLWH), COVID-19, Inactivated vaccine, Adverse event

People living with HIV (PLWH) tend to have high COVID-19 related morbidity and mortality [1]. UNAIDS suggested that PLWH should be given priority in COVID-19 vaccinations regardless of CD4 + T lymphocyte count (CD4 count) and HIV viral load (HIV$\mathrm{VL})$ levels [2]. The Chinese guideline also suggested that PLWH be given the inactivated vaccine or the recombinant subunit vaccine [3]. However, the safety of COVID19 vaccines among PLWH in China is unknown. This study aims to estimate the adverse events (AEs) rate after COVID-19 vaccination among PLWH.

Between April and July 2021, PLWH from the Wuchang district of Wuhan, China, aged between 18 and 59 years, were enrolled in this study. All participants received inactivated COVID-19 vaccine (Sinopharm, Wuhan Institute

\footnotetext{
*Correspondence: Weiming_tang@med.unc.edu; keliang@whu.edu.cn 'Songjie Wu Yubin Zhang and Fangzhao Ming contributed equally to this work

${ }^{7}$ The University of North Carolina at Chapel Hill Project-China,

Guangzhou, China

${ }^{10}$ Department of Nosocomial Infection Management, Department of Infectious DiseasesCenter of Preventing Mother-To-Child Transmission for Infectious Diseases, Wuhan Research Center for Infectious Diseases and CancerChinese Academy of Medical Sciences, Zhongnan Hospital of Wuhan University, Wuhan 430071, China

Full list of author information is available at the end of the article
}

of Biological Products Co. Ltd.) on day 0 and day 28 by intramuscular injection. Post-vaccination adverse events were evaluated seven days after each dose of vaccination. These adverse events include injection site pain, swelling, redness, fever, headache, fatigue, drowsiness, and cough.

In total, $91.1 \%$ of the PLWH (236/259) have taken both doses, while the remaining $8.9 \%$ have only taken the first dose of inactivated vaccine. Of all participants, 99.2\% were on antiretroviral therapy (ART), $80.3 \%$ were virally suppressed (208/259), and $81.1 \%$ had CD4 count $>350$ cells/ $\mu \mathrm{l}(210 / 259)$ at enrollment (Table 1$)$.

The overall AE rate was $22.8 \%$ after dose one (D1) of the vaccination, which was higher than that after dose two $(10.2 \%)$ ( $P<0.001)$. Local injection-site reactions were reported in $17.0 \%$ of the participants after D1 and $7.6 \%$ after D2. The most common systemic reactions included fatigue (3.5\% after D1, and $0.8 \%$ after D2, drowsiness (2.3\% after D1, and 1.7\% after D2), fever (1.9\% after D1, and 0.0\% after D2) (Fig. 1).

The majority of AEs were non-severe. The most common severe symptom after D1 included fatigue (3.1\%), drowsiness (2.3\%), and dizziness (1.9\%). The most common severe symptom after D2 was drowsiness (1.7\%). No other severe adverse events were observed. Compared with participants with other ART regimens (7.6\%), original author(s) and the source, provide a link to the Creative Commons licence, and indicate if changes were made. The images or other third party material in this article are included in the article's Creative Commons licence, unless indicated otherwise in a credit line to the material. If material is not included in the article's Creative Commons licence and your intended use is not permitted by statutory regulation or exceeds the permitted use, you will need to obtain permission directly from the copyright holder. To view a copy of this licence, visit http://creativecommons.org/licenses/by/4.0/. The Creative Commons Public Domain Dedication waiver (http://creativeco mmons.org/publicdomain/zero/1.0/) applies to the data made available in this article, unless otherwise stated in a credit line to the data. 
Table 1 Baseline data for all participants

\begin{tabular}{|c|c|c|c|c|c|c|c|c|c|}
\hline \multirow[t]{2}{*}{ Characteristic } & \multirow{2}{*}{$\begin{array}{l}\text { Patients with HIV/ } \\
\text { AIDS }(n=259)\end{array}$} & \multicolumn{4}{|c|}{ Dose $1(\mathrm{~N}=259)$} & \multicolumn{4}{|c|}{ Dose $2(N=236)$} \\
\hline & & $\begin{array}{l}\text { With } \\
\text { adverse } \\
\text { events }\end{array}$ & $\begin{array}{l}\text { Without } \\
\text { adverse } \\
\text { events }\end{array}$ & $x^{2}$ & $P$ & $\begin{array}{l}\text { With } \\
\text { adverse } \\
\text { events }\end{array}$ & $\begin{array}{l}\text { Without } \\
\text { adverse } \\
\text { events }\end{array}$ & $x^{2}$ & $P$ \\
\hline \multicolumn{10}{|l|}{ Age group } \\
\hline$\leq 35$ & 116 & 30 & 86 & & & 11 & 89 & & \\
\hline$>35$ & 143 & 29 & 114 & 1.14 & 0.29 & 13 & 123 & 0.13 & 0.72 \\
\hline \multicolumn{10}{|l|}{ Gender } \\
\hline Male & 240 & 55 & 185 & & & 21 & 197 & & \\
\hline Female & 19 & 4 & 15 & 0.04 & 0.85 & 3 & 15 & 0.90 & 0.34 \\
\hline \multicolumn{10}{|l|}{ Marital status } \\
\hline Singe & 169 & 42 & 127 & & & 17 & 136 & & \\
\hline Married & 36 & 6 & 30 & & & 3 & 31 & & \\
\hline Other & 54 & 11 & 43 & 1.36 & 0.51 & 4 & 45 & 0.43 & 0.81 \\
\hline \multicolumn{10}{|l|}{ Occupation } \\
\hline Unemployment & 37 & 7 & 30 & & & 2 & 33 & & \\
\hline Employment & 222 & 52 & 170 & 0.37 & 0.55 & 22 & 179 & 0.89 & 0.35 \\
\hline \multicolumn{10}{|l|}{ Education level } \\
\hline High school or lower & 76 & 17 & 59 & & & 6 & 62 & & \\
\hline Higher than high school & 183 & 42 & 141 & 0.01 & 0.92 & 18 & 150 & 0.19 & 0.66 \\
\hline \multicolumn{10}{|l|}{ Comorbidities } \\
\hline Yes & 38 & 6 & 32 & & & 5 & 30 & & \\
\hline No & 221 & 53 & 168 & 1.24 & 0.27 & 19 & 182 & 0.76 & 0.38 \\
\hline \multicolumn{10}{|l|}{ NNRTIs (NVP/EFV) } \\
\hline Yes & 216 & 47 & 169 & & & 17 & 180 & & \\
\hline No & 43 & 12 & 31 & 0.77 & 0.38 & 7 & 32 & - & 0.09 \\
\hline \multicolumn{10}{|l|}{ INSTIS (EVG/DTG) } \\
\hline Yes & 26 & 5 & 21 & & & 1 & 22 & & \\
\hline No & 233 & 54 & 179 & 0.21 & 0.65 & 23 & 190 & - & 0.48 \\
\hline \multicolumn{10}{|l|}{ Pls (LPV/r) } \\
\hline Yes & 14 & 5 & 9 & & & 5 & 8 & & \\
\hline No & 245 & 54 & 191 & 0.74 & 0.39 & 19 & 204 & 9.00 & 0.003 \\
\hline \multicolumn{10}{|l|}{ CD4 } \\
\hline$\leq 350$ & 49 & 8 & 41 & & & 5 & 38 & & \\
\hline$>350$ & 210 & 51 & 159 & 1.43 & 0.23 & 19 & 174 & 0.12 & 0.73 \\
\hline \multicolumn{10}{|l|}{ HIV viral load } \\
\hline Undetectable & 208 & 49 & 159 & & & 19 & 172 & & \\
\hline Detectable & 51 & 10 & 41 & 0.36 & 0.55 & 5 & 40 & - & 0.79 \\
\hline
\end{tabular}

NNRT/s nonnucleoside reverse transcriptase inhibitors; INST/s integrase inhibitors; Pls protein inhibitors; NVP nevirapine; EFV efavirenz; EVG elvitegravir; DTG dolutegravir; LPV/r lopinavir/ritonavir; - no statistics are computed because Fisher exact method was used

participants receiving protein inhibitor (PI) based antiretroviral regimen (all PI is lopinavir/ritonavir) reported more AEs $(38.5 \%)$ after D2 $(P<0.05)$. No significant differences in any AE rates were observed in other subgroups of PLWH $(P>0.05)$. After adjusted for age, sex, comorbidities, CD4 count, and HIV viral load with multivariable logistic regression model, receiving $\mathrm{LPV} / \mathrm{r}$ based regimen were still associated with increased $\mathrm{AE}$ risk in $\mathrm{D} 2(\mathrm{OR}=11.92,95 \%$ CI $2.63-54.00 ; P=0.001)$ (Table 2). We also found no difference in $\mathrm{AE}$ rates after each dose 


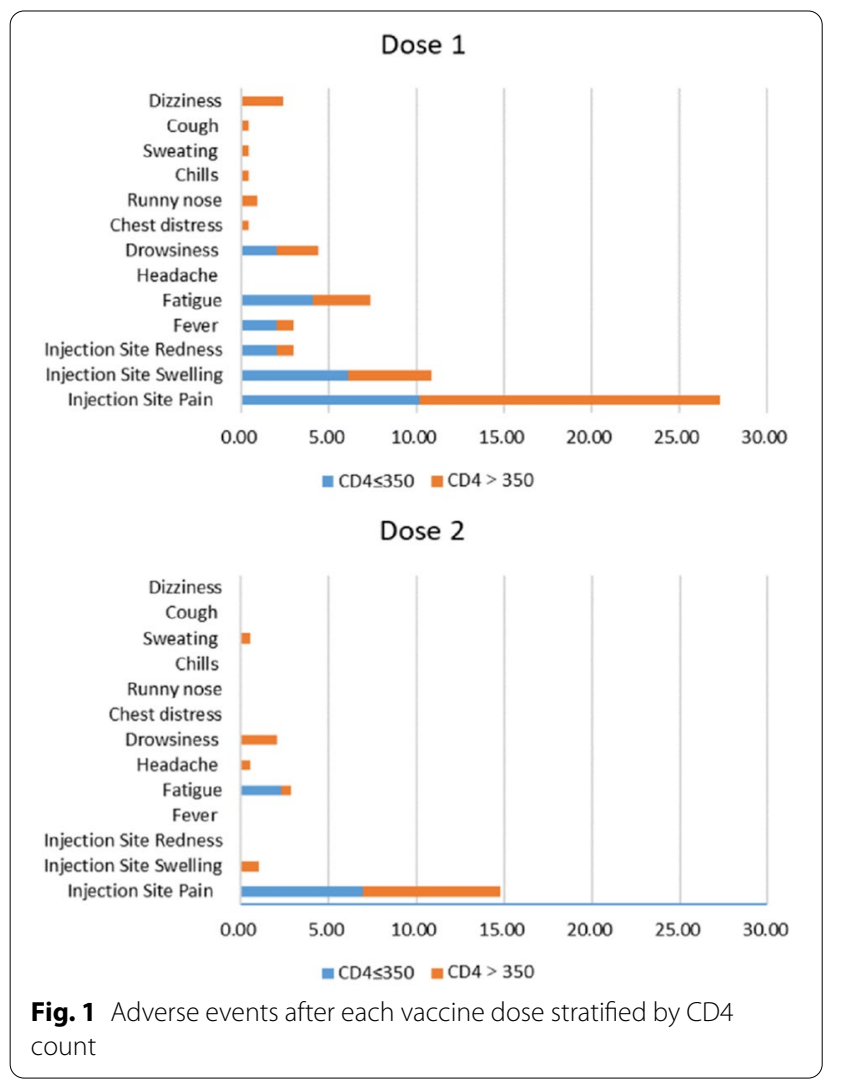

between participants with $\mathrm{CD} 4>350 / \mu \mathrm{L}$ and $\leq 350 / \mu \mathrm{L}$ $(P>0.05)$.

Concerns around AEs significantly impact ongoing vaccine hesitancy among PLWH. A previous national survey found that about $37.1 \%$ of PLWH are concerned that COVID-19 vaccination may have severe side effects [4]. Our study extended the existing literature by reporting AEs after COVID-19 vaccination among PLWH [5-7]. In our study, the AE rates were $22.8 \%$ after dose one (D1) of the inactivated COVID-19 vaccination and $10.2 \%$ after dose two, which was not higher than the $\mathrm{AE}$ rates of the original inactivated COVID-19 vaccine trials in general population $[8,9]$. The AE rates of inactivated COVID19 vaccine in our study was lower than that of mRNA COVID-19 vaccine $[5,6,10]$ and adenovirus vector COVID-19 vaccine [7]. We conclude the adverse events after the two-dose of inactivated COVID-19 vaccination among PLWH are minimal and mild. In addition, we also found that participants who were receiving LPV/r based regimen were more likely to experience AE after D2.

Our results have direct and immediate clinical implications. The data in this analysis are reassuring, finding no severe adverse event or vaccine safety concern among PLWH. There is an urgent need to disseminate this information to the vulnerable group of PLWH to minimize vaccine hesitancy and eliminate its refusal.

Table 2 Risk factors associated with AEs of inactivated COVID-19 vaccine in HIV-infected adults after dose 1 and dose 2: multivariable logistic regression analysis

\begin{tabular}{|c|c|c|c|c|}
\hline \multirow[t]{2}{*}{ Item } & \multicolumn{2}{|l|}{ Dose 1} & \multicolumn{2}{|l|}{ Dose 2} \\
\hline & Adjusted $\mathrm{OR}^{\mathrm{a}}(95 \% \mathrm{Cl})$ & $P$ & Adjusted $\mathrm{OR}^{\mathrm{a}}(95 \% \mathrm{Cl})$ & $P$ \\
\hline \multicolumn{5}{|l|}{ Age } \\
\hline$\leq 35$ & Ref. & & Ref. & \\
\hline$>35$ & $0.68(0.37,1.26)$ & 0.22 & $0.58(0.22,1.49)$ & 0.26 \\
\hline \multicolumn{5}{|l|}{ Gender } \\
\hline Male & Ref. & & Ref. & \\
\hline Female & $1.03(0.32,3.34)$ & 0.96 & $2.54(0.62,10.41)$ & 0.20 \\
\hline \multicolumn{5}{|l|}{ Comorbidities } \\
\hline No & Ref. & & Ref. & \\
\hline Yes & $0.66(0.26,1.70)$ & 0.39 & $1.85(0.60,5.71)$ & 0.28 \\
\hline \multicolumn{5}{|l|}{ Pls (LPV/r) } \\
\hline No & Ref. & & Ref. & \\
\hline Yes & $2.97(0.86,10.30)$ & 0.09 & $11.92(2.63,54.00)$ & 0.001 \\
\hline \multicolumn{5}{|l|}{ CD4 } \\
\hline$\leq 350$ & Ref. & & Ref. & \\
\hline$>350$ & $1.71(0.72,4.09)$ & 0.23 & $1.26(0.39,4.13)$ & 0.70 \\
\hline \multicolumn{5}{|l|}{ HIV viral load } \\
\hline Undetectable & Ref. & & Ref. & \\
\hline Detectable & $0.74(0.32,1.69)$ & 0.47 & $0.58(0.15,2.24)$ & 0.43 \\
\hline
\end{tabular}

${ }^{a}$ Each association was mutually adjusted for the other characteristics in the table 
Acknowledgements

Not applicable.

\section{Authors' contributions}

$\mathrm{KL}$ and WT participated in the inception of the idea of this manuscript with lead roles in conducting the study; SW involved in the data analysis and drafting of the manuscript; $Y Z$ and FM involved in data collection and interpretation; SZ, MW and WG was participated in discussion section. All authors read and approved the final manuscript.

\section{Funding}

This work was supported by the National Key Research and Development Program of China (2017YFE0103800), the National Nature Science Foundation of China (81903371), NIMH (R34MH119963), the National Science and Technology Major Project (2018ZX10101-001-001-003), and Special Found on Prevention and Control of New Coronary Pneumonia in Guangdong Universities (2020KZDZX1047), Medical Science and Technology Innovation Platform Support Project of Zhongnan Hospital, Wuhan University (PTXM2020008), Science and Technology Innovation Cultivation Fund of Zhongnan Hospital, Wuhan University (cxpy2017043). Medical Science Advancement Program (Basic Medical Sciences) of Wuhan University (TFJC2018004).

\section{Availability of data and materials}

All data generated or analyzed during this study are included in this article. The datasets generated and analyzed during the current study are available from the corresponding author on reasonable request.

\section{Declarations}

\section{Ethics approval and consent to participate}

This study was approved by the Research and Ethics Committee of Zhongnan Hospital, Wuhan University, People's Republic of China (2020079K-1), and informed consent was obtained.

\section{Consent for the publication}

$$
\text { Not applicable. }
$$

\section{Competing interests}

The authors declare that they have no competing interests.

\section{Author details}

${ }^{1}$ Department of Nosocomial Infection Management, Zhongnan Hospital of Wuhan University, Wuhan, Hubei, China. ${ }^{2}$ Wuchang District Center for Disease Control and Prevention, Wuhan, Hubei, China. ${ }^{3}$ Department of Infectious Diseases, Zhongnan Hospital of Wuhan University, Wuhan, Hubei, China. ${ }^{4}$ Department of Pathology, Zhongnan Hospital of Wuhan University, Wuhan, China. ${ }^{5}$ Department of Pathology, School of Basic Medical Sciences, Wuhan University, Wuhan, China. ${ }^{6}$ Guangdong No. 2 Provincial People's Hospital, University of North Carolina at Chapel Hill Project-China, Guangzhou 510095, China. ${ }^{7}$ The University of North Carolina at Chapel Hill Project-China, Guangzhou, China. ${ }^{8}$ Wuhan Research Center for Infectious Diseases and Cancer, Chinese Academy of Medical Sciences, Wuhan, China. ${ }^{9}$ Center of Preventing Mother-To-Child Transmission for Infectious Diseases, Zhongnan Hospital of Wuhan University, Wuhan, China. ${ }^{10}$ Department of Nosocomial Infection Management, Department of Infectious DiseasesCenter of Preventing Mother-To-Child Transmission for Infectious Diseases, Wuhan Research Center for Infectious Diseases and CancerChinese Academy of Medical Sciences, Zhongnan Hospital of Wuhan University, Wuhan 430071, China.

Received: 19 August 2021 Accepted: 17 November 2021 Published online: 04 December 2021

\section{References}

1. Wu Z, McGoogan JM. Characteristics of and important lessons from the coronavirus disease 2019 (COVID-19) outbreak in China: summary of a report of 72,314 cases from the Chinese center for disease control and prevention. JAMA. 2020;323(13):1239-42.

2. UNAIDS. COVID-19 vaccines and HIV. https://www.Unaids.Org/en/resou rces/documents/2021/covid19-vaccines-and-hiv. Accessed 14 Feb 2021.

3. Central People's Government of the People's Republic of China. Technical guidelines for the COVID-19 vaccination (First Edition). 2021. http://www. gov.cn/xinwen/2021-03/29/content_5596577.htm. Accessed 26 May 2021.

4. Vallée A, Fourn E, Majerholc C, Touche P, Zucman D. COVID-19 vaccine hesitancy among French people living with HIV. Vaccines. 2021;9(4):302.

5. Ruddy JA, Boyarsky BJ, Werbel WA, Bailey JR, Karaba AH, Garonzik-Wang $J M$, Segev DL, Durand CM. Safety and antibody response to the first dose of SARS-CoV-2 messenger RNA vaccine in persons with HIV. AIDS. 2021. https://doi.org/10.1097/QAD.0000000000003017.

6. Ruddy JA, Boyarsky BJ, Bailey JR, Karaba AH, Garonzik-Wang JM, Segev DL, Durand CM, Werbel WA. Safety and antibody response to two-dose SARS-CoV-2 messenger RNA vaccination in persons with HIV. AIDS. 2021. https://doi.org/10.1097/QAD.0000000000003017.

7. Madhi SA, Koen AL, Izu A, Fairlie L, Cutland CL, Baillie V, Padayachee SD, Dheda K, Barnabas SL, Bhorat QE, Briner C, Aley PK, Bhikha S, Hermanus T, Horne E, Jose A, Kgagudi P, Lambe T, Masenya M, Masilela M, Mkhize N, Moultrie A, Mukendi CK, Moyo-Gwete T, Nana AJ, Nzimande A, Patel F, Rhead S, Taoushanis C, Thombrayil A, van Eck S, Voysey M, Villafana TL, Vekemans J, Gilbert SC, Pollard AJ, Moore PL, Kwatra G. Safety and immunogenicity of the ChAdOx1 nCoV-19 (AZD1222) vaccine against SARSCoV-2 in people living with and without HIV in South Africa: an interim analysis of a randomised, double-blind, placebo-controlled, phase 1B/2A trial. Lancet HIV. 2021;8(9):e568-80.

8. Xia S, Duan K, Zhang Y, Zhao D, Zhang H, Xie Z, Li X, Peng C, Zhang Y, Zhang W, Yang Y, Chen W, Gao X, You W, Wang X, Wang Z, Shi Z, Wang Y, Yang X, Zhang L, Huang L, Wang Q, Lu J, Yang Y, Guo J, Zhou W, Wan X, Wu C, Wang W, Huang S, Du J, Meng Z, Pan A, Yuan Z, Shen S, Guo W, Yang $X$. Effect of an inactivated vaccine against SARS-CoV-2 on safety and immunogenicity outcomes: interim analysis of 2 randomized clinical trials. JAMA. 2020;324(10):951-60.

9. Xia S, Zhang Y, Wang Y, Wang H, Yang Y, Gao GF, Tan W, Wu G, Xu M, Lou Z, Huang W, Xu W, Huang B, Wang H, Wang W, Zhang W, Li N, Xie Z, Ding L, You W, Zhao Y, Yang X, Liu Y, Wang Q, Huang L, Yang Y, Xu G, Luo B, Wang W, Liu P, Guo W, Yang X. Safety and immunogenicity of an inactivated SARS-CoV-2 vaccine, BBIBP-CorV: a randomised, double-blind, placebocontrolled, phase 1/2 trial. Lancet Infect Dis. 2021;21(1):39-51.

10. Levy I, Wieder-Finesod A, Litchevsky V, Biber A, Indenbaum V, Olmer L, Huppert A, Mor O, Goldstein M, Levin EG, Hod T, Cohen C, Lustig $Y$, Rahav G. Immunogenicity and safety of the BNT162b2 mRNA COVID-19 vaccine in people living with HIV-1. Clin Microbiol Infect. 2021;S1198-743X(21):00423-7.

\section{Publisher's Note}

Springer Nature remains neutral with regard to jurisdictional claims in published maps and institutional affiliations.

Ready to submit your research? Choose BMC and benefit from:

- fast, convenient online submission

- thorough peer review by experienced researchers in your field

- rapid publication on acceptance

- support for research data, including large and complex data types

- gold Open Access which fosters wider collaboration and increased citations

- maximum visibility for your research: over 100M website views per year

At BMC, research is always in progress.

Learn more biomedcentral.com/submissions 